\title{
The RICS service charge code of practice - Evolution or revolution?
}

Received (in revised form): 9th January, 2008

\section{Peter Forrester}

is Director, Service Charge Consultancy, Savills Commercial Limited and a member of the Service Charge Code of Practice Steering Group and has been appointed to the RICS President's Panel of Independent Service Charge Experts.

Correspondence: Peter Forrester, Service Charge Consultancy, Savills Commercial Limited, 25 Finsbury Circus, London EC2M 7EE, UK; Tel: + 44 (0) 207409 8948; Fax: +44 (0) 207454 1333; E-mail: pforrester@savills.com

\begin{abstract}
In response to industry concerns to the threat of government intervention in the commercial sector, the RICS have produced a new Code of Practice for service charges in commercial property that represents best practice in the management and administration of common services and the recovery of costs from occupiers. This article provides an overview of the Code and the implications for owners and managers of commercial property.
\end{abstract}

Journal of Building Appraisal (2008) 3, 297-303. doi:10.1057/jba.2008.2

\section{Keywords:}

service charge, best practice, communication, transparency, total cost of management, value for money

\section{BACKGROUND}

Statutory regulation of residential service charges was first introduced under the Housing Finance Act 1972 and successive legislation, notably the Landlord and Tenant Act 1985 and the Commonhold and Leasehold Reform Act 2002, has afforded residential tenants even greater protection against abuse.

Tenants of commercial property have no such statutory protection and it is the contractual terms of the lease that sets out the terms and operating mandate of the service charge arrangements.

In theory, service charges are relatively simple: in granting a lease of premises in a multi-occupied building the landlord will retain responsibility for the maintenance and repair of those areas of the building outside of the tenanted demise, for example the exterior and structure, common areas, etc and will also covenant to provide various services, for example heating, cleaning, etc. The tenant for its part agrees to reimburse the landlord a proportion of the costs incurred in complying with these retained responsibilities and the provision of the services. In essence, a service charge regime is intended to put a tenant broadly in the same position as if it had taken a lease under full repairing and insuring terms.

Service charges, however, are frequently cited as one of the most common sources of conflict in the landlord and tenant relationship often, in the authors experience, due to a lack of understanding of the purpose of the service charge provisions and also due to the fact that many landlords consider a service charge regime to be a source of additional profit or as a way of recovering costs beyond that which would normally be expected of or enforced upon a tenant occupying under a full repairing and insuring lease. 


\section{KEY OBJECTIVES OF THE CODE}

The key objectives of the Code are to

- remove service charges as an area of conflict;

- deliver a budgetable and forecastable part of the occupiers overheads that represents value for money;

- ensure service charges that are not for profit, not for loss and are cash neutral to the owners income stream;

- encourage transparency and communication in the relationship between landlords and tenants;

- provide for cost-efficient and expert dispute resolution.

The Code, launched on 26th June, 2006, has pan-industry and government endorsement and came into effect for service charges commencing from 1st April, 2007 and is applicable in England and Wales. The Code of Practice has also been adopted in both Scotland and Northern Ireleand for service charges commencing from 1st April, 2008.

The Code has been produced by a panel of experts representing various industry organisations and the steering group consulted closely with the stakeholders and also sought feedback from across the industry. The Code is supported by the government and is endorsed by the British Council for Offices, British Council of Shopping Centres, British Property Federation, British Retail Consortium and the Property Managers Association.

\section{COMPLIANCE}

The Code cannot override the provisions of the lease but encourages the parties to interpret existing service charge clauses in accordance with the principles and practices set out in the Code.

The Code is not mandatory and does not lay down rules of professional conduct but provides advice to landlords who wish to manage buildings well and avoid disputes. The Code has the status of a formal RICS Guidance Note and while practitioners are not required to follow the advice and recommendations contained in the Code, the courts are likely to have regard to the Code in deciding any professional negligence claim.

There may be some instances where recommended best practice cannot be applied. In such circumstances, practitioners should always explain why this is the case and keep a record of their reasoning.

The Code also recommends that new or renewed leases (where permitted by law) should be granted to reflect the standards as set out in the Code and, if necessary, the rent should be adjusted to reflect this.

The Code has been written with larger multi-occupied properties in mind. A common sense approach is therefore needed in applying the principles of the Code to smaller properties particularly where strict compliance with the Code would not produce a valuefor-money solution.

\section{WHAT SHOULD A NEW LEASE CONTAIN?}

The service charge provisions of new leases should be drafted in a way that seeks to achieve rather than defeat or circumvent the best practice aims and objectives set out in the Code. 
The service charge should be on a 'not for profit, not for loss' basis and be cash neutral to the owner's income stream. This does not mean that service providers cannot make a reasonable profit on the services they provide (or managers cannot make a profit on their management services) but that the costs should be transparent. The total cost recovered should not be inflated for additional profit. Similarly (assuming the property is fully let with no concessions on service charge costs to specific occupiers) the owner, complying with the provisions of the Code, should recover all costs properly incurred in providing the building services.

Nor should the owner recover the cost of improvements that go beyond the cost of normal maintenance, repair or replacement.

Owners, however, are likely to face a number of potential problems when seeking to modernise the service charge regime. Not all leases within a property will expire at the same time and until such time as all leases have been renewed in a modern format, discrepancies between leases could result in different service charge arrangements that could give rise to anomalies in the recovery of costs. It might therefore be necessary for the landlord to continue to operate the service charge under the old regime until a critical mass of new modern leases is in place.

Lease renewals are also governed by S 35 of the Landlord \& Tenant Act 1954, which allows for modernisation of lease terms, although this is to some extent limited by the decision in the leading case of O'May $v$ City of London Real Property Company [1982] 1 All ER 660. Although this concerned a situation where the landlord sought to introduce a service charge provision where one did not previously exist, the principle established by the case is that an adjustment in the rent payable may not be adequate compensation to reflect the transfer of risk to the tenant of an increased liability for future unquantifiable costs.

Where a service charge provision already exists it is anticipated that the parties should be able to agree modernisation of the lease to reflect the principles set out in the Code, although it will probably be easier for the tenant to secure changes in line with the principles of the Code particularly if the terms of the existing lease seem unreasonably harsh or onerous.

While landlords may be faced with these problems it is clear that to do nothing is not a viable alternative and to avoid government intervention, similar to that which already exists in the residential sector, landlords must accept they have a vital role to play in moving our industry forward and to demonstrably embrace best practice.

\section{THE CODE}

The Code sets out best practice principles in the management and administration of service charges in commercial property. The Code comprises four parts and is supported by a technical section and appendices giving notes on specific topics and illustrations as to how the principles outlined in the Code can be achieved.

\section{Management}

This section covers the owner's duty to manage and the occupiers' right to challenge the propriety of expenditure.

The owner has a duty of care to ensure that the standards of services provided are monitored, that the quality and cost of the services are regularly reviewed and to demonstrate that services are provided on a value-for-money basis. 


\section{Communications}

Effective communication is considered to be the key to achieving best practice. The Code promotes good administrative and business practice between owners and occupiers and encourages good working relationships, through consultation, about the services that are required, their quality and cost.

When significant variances (eg of more than 2 per cent above RPI) in actual year-onyear costs against budget are likely, the owner will notify occupiers promptly.

\section{Transparency}

This is seen as an essential element to improving communication. Transparency in the service charge accounts and information provided to occupiers will prevent disputes.

The Code recommends a cost code structure for the presentation of accounts that is compatible with published service charge indices such as Jones Lang LaSalle's 'OSCAR ${ }^{\mathrm{TM}}$ ', which will facilitate benchmark comparison of costs.

\section{Service standards and provision}

All services should be provided both commercially and professionally. The Code looks at methodologies for the procurement of services in order to ensure services provide value for money and to ensure that services are beneficial and relevant to the needs of the property, its owner, occupiers and their customers/visitors.

Service charge cost will be restricted to charges and associated administrative costs properly incurred by the owner in the operational management of the property. This includes the reasonable cost of maintenance, repair and replacement (where beyond economic repair) of the fabric, plant, equipment and materials necessary for the property's operation.

Service charge cost will not include

(i) any initial cost incurred in relation to the original design and construction;

(ii) any setting up costs;

(iii) improvement costs above the cost of normal maintenance, repair or replacement;

(iv) future development costs;

(v) costs that are matters between an owner and an individual occupier such as rent collection, consents for assignments, sub-lettings, alterations, dealing with rent reviews etc; and

(vi) any costs arising out of the failure/negligence of the manager or owner.

Service charge cost may include enhancement of the fabric, plant or equipment where such expenditure can be justified following the analysis of reasonable options and alternatives.

\section{Administration}

\section{Management fees}

This is a potentially contentious area as many view the Code as an occupiers' charter to demand more and better services but at an increasingly lower cost. The Code makes a clear statement that the conventional fee based on a percentage of expenditure is no longer appropriate and can often be seen as a disincentive to the delivery of value for money. The fees should be the reasonable price for the total cost of managing the provision of the services. The Code recommends that the total price will be a fixed fee for 
a reasonable period (eg three years) and may be subject to indexing. The fee should be reasonable for the work done in relation to the operation and management of the services and have due regard to the work necessary to fulfil the principles of the Code.

While for some larger properties such as shopping centres, this might result in a reduction in fees to reflect the responsibilities of the on-site management team in managing and administering the services and a corresponding reduction in workload for the managing agent or landlord, an increase in fees for smaller or more intensively managed properties may be appropriate to reflect the disproportionate workload necessary compared to the overall cost of the services. This is therefore an area both owners and managing agents are likely to review.

\section{Apportionment}

The technical section provides a commentary on various methodologies for apportioning costs between tenants. Whatever method is used it needs to be demonstrably fair and reasonable and an apportionment schedule should be made available to all occupiers showing the total apportionment for each unit at the property.

If the property is fully let then the owner will normally be able to recover all expenditure on services through the service charge, except any concessionary discounts the owner has given.

New leases should enable the owner to vary the basis of apportionment to reflect the benefit to occupiers of specific services and any change in circumstances over time and that are considered ought to be a factor in determining the apportionment of costs, for example hours of use. Where the basis or methodology is altered owners are to provide a detailed explanation of the rationale and basis of calculation.

\section{Budgets/accounts}

The Code sets down time limits for the issuing of service charge budgets (one month prior to the commencement of the service charge year) and year-end accounts (within four months of the year end). The accounts should include an adequately detailed and comprehensive summary of items of expenditure with full explanations of any material variations.

The Code recommends that owners will allow occupiers a reasonable period (eg four months) in which to raise queries in respect of the certified accounts and will deal with reasonable enquiries promptly and efficiently.

\section{Change of owner or agent}

Not later than four months following the date of completion of a sale, the seller will provide the buyer with full details of all service charge information for all outstanding service charge years up to the date of sale.

\section{Sinking, replacement and reserve funds}

In addition to regular expenditure on services, owner and occupiers may need to make provision for occasional one-off outlays on replacing major items of equipment (eg a heating system). Major expenditure of a regularly recurring nature (ie external redecorations) can also cause significant fluctuations in the amount of service charge payable each year.

To the extent that these items can be foreseen, it may make sense to spread the cost over a number of years by setting up a sinking fund, replacement fund or reserve fund, 
rather than charging the whole cost to the current occupiers in the year in which the equipment is replaced.

The Code provides much needed clarity in the distinction between sinking funds and reserve funds and also emphasises that where such arrangements are operated:

(i) All monies should be held in trust separate from the owner's own monies.

(ii) That the owner will act reasonably in estimating the amount of contributions included within the service charge, which will relate to specifically identified expenditure only.

(iii) The owner will provide a clear explanation of the calculation of the contributions having regard to a realistic assessment of the anticipated lifecycle of the item in question.

(iv) On completion of a sale, the seller will pass all monies held, including accrued interest, to the buyer.

\section{Alternative dispute resolution}

There is no statutory requirement for the Code to be taken into account when dealing with disputes. But while as yet untested with regard to the Service Charge Code, the courts have had regard to industry Codes of Practice when determining disputes in other areas and leading barristers are of the opinion that the courts are therefore likely, in appropriate circumstances, to have regard to the Service Charge Code in settling service charge disputes.

The RICS intends that the Code provides access to alternative dispute resolution (ADR) for parties involved in disputes about service charge matters.

ADR has been introduced because the courts have been increasingly encouraging parties to resolve disputes between them without the need to go to trial. Failure to consider ADR as a means to resolving a dispute could result in penalisation on costs even for the successful party to the litigation.

The Code describes the RICS Dispute Resolution Service and recommends mediation or expert determination as appropriate forms of ADR for service charge disputes.

Mediation involves the introduction of an impartial third party to provide understanding and empathy to both sides to the dispute with the aim of getting the parties to agree a mutually agreeable solution.

Alternatively, where the parties are unable to reach an overall agreement or the dispute involves a particular technical or legal issue, the dispute might be referred to an independent third party who is trained and experienced in the subject matter under dispute. The independent expert will apply their expert knowledge to the situation and make a binding determination on the matter.

The RICS have now appointed a panel of independent expert surveyors who can be called upon to assist in determining disputes.

\section{CONCLUSION}

In the unreported case of Princes House Ltd v Distinctive Clubs Ltd [2006] the trial judge prompted by the circumstances of the case before him commented:

'Tenants who agree to service charge clauses under which they contract to pay against a surveyor's estimate or an accountants certificate rely upon the professional people involved performing their roles with professional scrupulousness, diligence, integrity and independence and not in a partisan spirit, supposing their only task to be to recover as much money as they can for the landlord ... such reliance can often be misplaced'. 
Regrettably the circumstances of this case are, in the author's experience, all too common although disputes rarely end up in the courts.

The new Code of Practice emphasis the duty of care that owners owe to occupiers in ensuring that services are professionally managed and administered and procured on a value- for-money basis.

The Code cannot cover all eventualities but lays down best practice principles for the interpretation of existing leases and for the modernisation of new leases when the opportunity arises.

Implementing the Code in whole or in part will have cost and time implications for owners and their managing agents. Failure, however, by the commercial property industry at large to get its house in order by embracing and adopting the principles set down in the Code may see the government intervene with the introduction of legislation similar to that which already exists in the residential sector.

Germaine Greer once said that 'Revolution is the festival of the oppressed' and the introduction of legislation to protect tenants from abuse might be considered by many to be revolutionary.

Nevertheless, the Code advocates an evolutionary process in doing away with what is often seen as an adversarial landlord and tenant relationship and in moving towards a situation where the parties are seen more as supplier and customer.

For further information see:

www.rics.org

www.savills.co.uk/servicecharge

www.servicechargecode.co.uk 